\title{
Sanayi Devrimi Başlangıcında İstanbul'da Boyacı Esnafı Örneğinde Tekstil Sanayisinin Durumu ${ }^{1}$
}

\author{
The Status of the Textile Industry in the Case of Painter Tradesmen in Istanbul \\ at the Beginning of the Industrial Revolution
}

Tahir ÖĞÜT²

Article Info

Article History:

Date Submitted: 07.08.2019

Date Accepted: 12.09.2019

Jel Classification

N10, N70, 014

Keywords:

Ottoman Empire,

Painting, Foundations,

Financial Accumulation

\begin{abstract}
In the Ottoman Empire, the first half of the 18th century was a period of economic development and financial accumulation. In Europe, the industrial revolution is taking place, which will have global consequences. The textile sector stands out as an immersive sector in the industrial revolution. The determination of the developments in the dyeing sector in terms of its direct relationship with Istanbul as a field of activity and the determination of the developments in the textile sector in the Ottoman economy is an explanatory feature. Founded in Istanbul in the 18th century as the mite of the sultan foundations such as the Sultan Ahmet Foundation Library and the Laleli Fountain, the establishment of dyehouses in this period was the public investment as a result of the development in the Istanbul textile sector.
\end{abstract}

\section{ÖZET}

Osmanlı devletinde 18.yüzyıl ilk yarısı ekonomik gelişimin ve mali birikimin gerçekleştirildiği bir dönemdir. Avrupa'da ise küresel sonuçlar doğuracak olan sanayi devrimi gerçekleştirilmektedir. Sanayi devriminde sürükleyici bir sektör olarak tekstil sektörü öne çıkmaktadır. Osmanlı ekonomisinde tekstil sektöründeki gelişimi belirleyebilmek bakımından yer olarak İstanbul, faaliyet konusu olarak da diğer tekstil sektörleriyle doğrudan ilişkisi bakımından boyacılık sektöründeki gelişimlerin belirlenmesi açıklayıcı bir özellik arz etmektedir. İstanbul'da 18.yüzyılda Sultan Ahmet Vakfı Kütüphanesi ve Laleli Çeşmesi gibi sultan vakıflarının akarı olarak kurulan vakıfların boyahaneler tesis etmeleri bu dönemde İstanbul tekstil sektöründeki gelişimin sonucu olarak gerçekleşmiş kamusal yatırımlardır.

\footnotetext{
${ }^{1}$ Bu çalışma 20-21 Nisan 2017'de Harran Üniversitesi İktisadi ve İdari Bilimler Fakültesinde düzenlenen II.Ulusal EconHarran İktisat Kongresinde "18.yüzyılda Tekstil Sektöründe Gelişim: İstanbul Boyacı Esnafı Örneği” isimli sözlü bildirinin genişletilmesiyle oluşturulmuştur.

${ }^{2}$ Dr. Öğr. Üyesi, Harran Üniversitesi İiBF İktisat Bölümü
} 


\section{GíRIŞ}

Batı Avrupa'da 18.yüzyılda tekstil sektöründeki gelişim sanayi devrimi çağını başlatmaktaydı. $\mathrm{Bu}$ dönemde İstanbul üzerinden tekstil sektörünü incelemek Osmanlı tekstil sektörünün durumunu belirleyebilmek bakımından oldukça açıklayıcıdır. Çünkü İstanbul tüketim merkezi bir başkent olması kadar coğrafi konumundan dolayı önemli bir üretim merkezi olma özelliğini de tarihsel süreçte kesintisiz olarak devam ettirmiştir. Ancak böylesi bir çalışmada tekstil sektörüne yönelik periyodik raporların ve kayıtların eksikliği dolaylı kaynakların kullanımını zorunlu olmaktadır. Tekstil sektöründe oldukça geniş bir ekonomik faaliyet olmasından dolayı, çalışmanın kapsamı tekstil sektörünün geneliyle ilintili yapıya sahip olan boyacılık sektörü üzerinden gerçekleştirilmiştir ${ }^{3}$. Araştırmanın temel kaynağını İstanbul Ahkam Defterlerine göre “İstanbul Esnaf Tarihi I-II” başlıklı eserler oluşturmuştur".

\section{Osmanlı Devleti’nde 18.Yüzyıl'da Boyacılık Sektörünün Genel Görünümü}

Osmanlı Devleti'nde 18.yüzyıl ilk yarısı iktisadi genişleme dönemidir (Öğüt, 2018:265-290). Sanayi alanında da iktisadi gelişimde dokumacılık sektörü öncelikli konumdadır. İstanbul, Bursa, Halep, Şam, Menemen ve Sakız gibi dokumacılıkta öncelikli konumdaydı. Dokumacılık sektöründeki gelişimi boyacılık gibi yan sektörlerin gelişimini de sağlamaktaydı ( Tabakoğlu, 1994:224).

Boyahanelerin zamanla artan ve azalan sayıları tekstil sanayisindeki gelişimin belirlenmesi bakımından önemli bir göstergeydi ${ }^{5}$ (Ouataert,2013:134). Bu sektörde 18.yüzyılda kaydedilen gelişmeler genel olarak dokumacılık sektöründeki gelişimin de göstergesi olmuştur. ${ }^{6}$ (Çınar,2013:33-53).

\footnotetext{
${ }^{3}$ Kumaş üretimine yönelik çalışmalarda en önemli sorun konu hakkında doğrudan veri sağlayacak olan belgelerin bulunmamasıdır. ( Faroqhi, 2000:155).

${ }^{4}$ Cumhurbaşkanı R. Tayyip Erdoğan'ın İstanbul Büyükşehir Belediye Başkanlığı döneminde, İstanbul Ahkâm Defterleri, Belediye Kültür AŞ tarafından kapsamlı bilimsel bir projeye konu olmuştur. Projeye çerçevesinde arz edilen eserler, İstanbul Ahkâm Defterlerini İstanbul Esnaf Tarihi, Finans Tarihi, İstanbul'da Sosyal Hayat ve İstanbul Tarım Tarihi gibi konu başlıklarıyla yayımlanmıştır. Belirtilen başlıklarda eserlerin yayımlanması, Ahkâm Defterlerini kronolojik olarak belirtilen konu başlıklarına göre tasnif edilmesine dayalı metodun benimsenmiş olmasından kaynaklanmıştır. Bu çalışma aynen belge kopyası ve transkripti olmasından dolayı araştırmacılar bakımından oldukça değerli bir araştırma kaynağını oluşturmuştur.

${ }^{5}$ Ouataert Halep'te 19.yüzyılda tekstil sektörünün gerilememiş olduğu tezini boyahane faaliyetlerinin gerilememiş olmasına dayandırmaktadır. ( Ouataert, 2013:134).

${ }^{6}$ Mesela 18.yüzyıl başına kadar Ayntab'da(Gaziantep) Hüsrev Paşa vakfı akarından 3 boyahane olmasına karşın, Acem bezi dokumacılığında bu yüzyılın başında gerçekleşmenin sonucuna bağlı olarak yeni kurulmuş 8 vakfa ait toplamda 10 boyahane faaliyete geçmiştir. Bir vakıf akarına ait olmayan boyahanelerin sayısı da 53'e ulaşmıştır. 1769 'da boyahane sayısı 68'e çıkmıştır. Dokumacılığı 18.yüzyıl ilk yarısında gelişimi bakımından $1728^{\prime}$ den $1757^{\prime}$ e
} 
Osmanlı dokumacılık sektörü 18.yüzyılda genel olarak artan iş hacminin sonucu olarak emek arzının yetersizliği ve ücretlerin artışı sorunuyla karşılaşmışt1 ${ }^{7}$. ( Tabakoğlu, 1994:220).

Osmanlı'da boyahaneler 19.yüzyıl ortalarında Avrupa menşeili endüstriyel boyaların ve boyanmış ipliğin piyasaya girdiği aşamaya kadar tekelci kuruluşlar olarak varlıklarını etkin bir şekilde devam ettirdiler (Ouataert,2013:54). Osmanlı boyacılık sektörünün sürekliliği tekelci bir üretim ilişkisinin sonucu olduğu kadar, üretim standartlaştırmasının sonucu olan yüksek kaliteden taviz verilmemesinin sonucuydu. Boyacı sektörünün ulaşılmış olan yüksek standart uluslararası alandan da dikkatleri çekmekteydi. İngiltere'nin 17.yüzyıl başlarında tekstilde yüksek atılım gerçekleştirdiği aşamada Kraliçe Elizabeth'in Osmanlıda boyacılık tekniğinin öğrenilmesi için İstanbul'a casuslar gönderildiğine dair iddialar da bulunmaktadır (Avcıoğlu,2013:11) .Şevket Pamuk’un yaklaşımına göre genel olarak esnafın tekele dayalı üretim organizasyonu mesleki bir örgütlenmeden ziyade devletin üretim ve vergilendirme sürecini kontrol etmesini sağlayan yapılardı ( Pamuk, 2017:58).Boyahanelerin mali sisteme eklemlenmeleri ise mukataa sistemine dâhil edilmeleriyle gerçekleştirilmekteydi ( Ouataert, 2013:127). Böylelikle boyahanenin bir vergi konusu olarak mukataaya bağlanması ve hazineye gelirlerinde istikrarın güvencesini oluşturmaktayd1. ${ }^{8}$ (C.İKT, 38/ 1863, H.23-12-1178). Boyahanelerin mukataa sistemindeki konumlarında mali gelirlerinin sürekli arttırılmasından ziyade gelirde istikrarın sağlanması amacını taşımaktaydı. Mehmet Genç İstanbul'da 18.yüzyılda tekstil sektörünün gelişimi belirlemek için yapmış olduğu çalışmada İstanbul'da 1706- 1800 yılları arasında İpekli Kumaş Damga Vergisi senelik gelirlerindeki tek düzeyliği tespit etmiştir. İpekli Kumaş Damga Resmi 1712'de 4000 guruş iken 1800'e kadar süreçte bu mukataa geliri değişmeksizin aynı seviyede kalmıştır ( Genç, 2000: 132).Ancak vakıfların boyahane gelirlerindeki istikrar vergilerin iş hacminden bağımsız olarak belirlendiği anlamına gelmemektedir. Mesela Mehmet Genç'in 1758- 1777 yılları arasındaki süreçte önemli bir tekstil merkezi olan Tokat'a yönelik olarak gerçekleştirdiği araştırmada, Boyahane ve Kırmızı Bez

kadar olan süreçte Ayntab'dan Marsilya'ya bez ihracatının \%80 artmış olması gösterilebilir (Çınar, 2013 :3353).

7 18.yüzyılda dokumacılık sektöründe emek arzının sınırlı olmasının sonucunda Bursa'da köle emeğinin kullanımında artış gerçekleşmiştir. ( Tabakoğlu, 1994:220).

${ }^{8}$ Suruç'ta Molla Mehmet Şevkan Karyesinde 1156 'da inşa ettirdiği caminin vakıf akarına tesis edeceği yine aynı karyede bir boyahane için Suruç mukataasına senelik beş guruş vermeyi garanti etmişti. (C.IKT, 38/ 1863, H.2312-1178). 
Damgası mukataası gelirlerinin Rus savaşının 1768'de başlaması üzerine ciddi seviyelerde azaldığını belirlemiştir ( Genç, 2000: 281). Boyacı mukataalarının oluşumu sadece kurulu bir tesisin mali sisteme eklemlenmesi olmayıp, 18.yüzyılda Tokat boyahanesi örneğinde olduğu gibi mali sistem üzerinden iktisadi üretimin genişletilmesi politikasına da dayanmaktaydı. ${ }^{9}$ ( Genç,2000:106). Mehmet Genç boyahane faaliyetlerini mali bakımdan değerlendirdiği gibi kamusal sermaye yatırımları perspektifinde de değerlendirmiştir. Genç’e göre yüksek tutarlı sabit sermaye yatırımı gerektiren yatırımlar devlet tarafından gerçekleştirilmekteydi. Devlet yatırımlarında boyahane ve bedesten gibi yüksek maliyet gerektiren yatırımlar öne çıkmaktaydı (Genç,2000:106). Bu bağlamda İstanbul'da selatin vakıflarının boyahane yatırımları öne çıkmaktaydı. Taşrada boyahane yatırımlarına Urfa' da 18.yüzyılda hazineden kuruluş sermayesi desteği almış olan Rızvaniye Vakfı önemli bir örnektir (Ögüt,2019:357-376). Suraiya Faroqhi’e göre de boyahane faaliyetleri kooperatif modeli olarak değerlendirmiştir ( Faroqhi, 2000:182). Gerçekten de ortak hammadde alım ve işin tevzii gibi uygulamalarıyla boyahaneler modern üretim kooperatiflerin öncüsü olma özelliğini göstermekteydi. Boyacılık sektöründeki lonca örgütlenmesi genel ekonomik dengenin kurulması ve sürdürülmesi amacı da taşımaktaydı. Böylelikle bireysel tekelleşmelerle sermaye birikimini sınırlı ellerde toplanmasını engellemek ve böylelikle tekelleşen sermayeye dayanarak ön satım sözleşmelerine dayalı olarak piyasa da fiyat istikrarın korunması ile boyacılık sektörüne dayalı diğer tekstil dallarında da gelir kayıplarını önleyici bir anlayışı da içermekteydi. ${ }^{10}$ (A.DVN.MHM. 10/237,h. 17.10.979). Boyahanelerin kuruluşları salt iktisadi ve mali amaçlarla belirlenmeyip, vakıf hukuku bakımından da bağlayıcı kurallara tabiiydi. Çünkü bir vakıf akarına bağlamak için boyahane inşa edilmesi, faaliyetteki diğer vakıf mütevellilerinin de ön onaylarını gerektirmekteydi ${ }^{11}$. (Çınar,2013 :33-53). Bu konuda başlıca kriter ise diğer boyahanelerin zarar görmemesiydi ${ }^{12}$.

\footnotetext{
${ }^{9}$ Tokat Mukataasında malikâne hissedarı olan Atıf Mustafa Efendi Boyahaneyi gerçekleştirmiş olduğu yatırımla genişletmesi sonucunda, Tokat Boyahanesinin üretimi 1723-1742 yılları arasında \%70 oranında artmıştır (Genç, 2000: 106).

${ }^{10}$ Bursa'da h.979'da zenginleşmiş olan boyacılardan Yusuf ve dört arkadaşı bu şehre Boğasi boyanmak için getiren esnafa ön satın alım sözleşmesine dayalı olarak borç vermeleri, diğer esnaf tarafından şikayete konu olmuştur. (A.DVN.MHM. 10/237,h. 17.10.979).

${ }^{11}$ Kilis Voyvodası Hüseyin Ağa Kilis'te inşa ettiği vakfın gelirine bağlanmak için boyahane kurmasına h.4-51105 'de izin verilmişti. AE. SAMD. II, 20/ 2186. Antep'te16.yüzyılda kurulan Hüsrev Paşa Vakfının akarlarından olan boyahanenin gelir seviyesini korumak maksadıyla vakfiye senedinde serbest boyahanelerin kurulması vakıf mütevellisinin izin şartına bağlanmıştır. ( Çınar, 2013:33-53).

${ }^{12}$ Larende 'de bir boyahanenin Çavuş Oğlu Abdurrahman tarafından verilen arzuhalle açılması talebi, mevcut mukaataya tabi boyahanenin aleyhine sonuçlar doğuracağı gerekçesiyle h.29.2.1133'de ret edilmişti. (C.IKTS, 26-02-1133, h.29.2.1133).
} 
(C.İKTS, 26- 02-1133, h.29.2.1133). Boyacılık faaliyetleri tekelci bir üretim ilişkisine dayanmaktaydı. Ancak tekstil iş kolundaki tekelci üretim ilişkisi tüm sektörler bakımından mutlak bir bağlayıcılığa sahip değildi. Mesela iplik eğirme işinin tekel hakkı Balkapanın da mukim olan Hallaç esnafina ait olmasına karşın bu iş kolunda tekel hakları toplumun dezavantajlı kesimleri olan yetim ve dul kadınlarına yönelik olarak esnetilmişti (Kal,1997, Cilt II :25).Osmanlı tekstil sanayisindeki tekelci üretim yapısı Avrupa'da da benzer özelliği göstermekteydi Batı'da sanayi devriminin taşıyıcı sektörü olan tekstil alanında kumaş imalatı 18.yüzyılda katı standartlara tabiiydi. İngiltere'de 1720'de çıkarılan şirketler yasası uyarınca anonim şirket kurmak parlamentonun özel onayına başlı olarak sınırlandırılmış imtiyazlı bir faaliyet alanıydı. Ancak yünlü kumaş imalında uygulanan katı lonca kuralları pamuklu dokuma sektöründe geçerli değildi. İngiltere'de katı lonca kurallarının uygulanmadığı pamuklu dokumacılık sektörü 18.yüzyılda İngiltere dokumac1lık sektöründeki büyük atılımın itici gücü olmuştur ( Deane, 1994 :195). İngiltere'de yünlü dokumacıllk faaliyetlerine göre daha liberal faaliyet alanına sahip olan pamuklu dokumacılık sektörü dış ticarette ise uluslararası ticari tekelciliğe dayanarak yürütülmekteydi. East India Company'in Hindistan üzerinden gerçekleştirilen pamuk elyafı ve kumaşları ticaretinde 1600 'da kraliyet beratına dayalı olarak tekel hakkı sağlanmıştı. Ancak bu şirket tekelinin 1813'de sona ermesi ve ilerleyen tekstil ihracatı sonrasında İngiltere'nin ihracatı ciddi şekilde artmıştır. Hindistan'a ihracat edilen pamuklu dokumaların fiziki tutar1 1814'de 1 milyon yarda iken( 1 yarda 0,9144 metre) 1830'da 51 milyon, 1870'de ise 995 milyon yardaya çıkmıştı. İngiltere'nin dünya imalat sanayi içindeki yeri ise 1800 'de 0,28 'den 1830 'da 0,342 'e, 1860 'da ise 0,532 'e çıkmıştır ( Kennedy, 2008:191).EIC’nın Osmanlı ticareti 18.yüzyıl sonlarına doğru Basra'da İngiliz ticareti muslin bezi, geniş enli dokumalar ve ince yünlü dokumalardan oluşan düşük ölçekli bir ticaretle sınırlanmıştı. $\mathrm{Bu}$ malların satışından elde edilen kârlar nadiren fabrika kuruluşunun maliyetlerini karşılayabilmekteydi ${ }^{13}$. ( Bamforth, 1948:19). EIC'nin Ortadoğu'ya ilgisi İngiliz tekstil sektörünün 19.yüzyılda artan hammadde ihtiyacını karşılamaya yönelik alternatif üretim alanlarının oluşturulması amacına uygun olarak gerçekleşmiştir. Mezopotamya 7-8 aylık yağmursuz yaz sezonuna sahip olması alternatif üretim alanları arayışında dikkatleri bölgeye çekmiştir (Earle,1903-1923:24). Ancak Osmanlı yönetimi Ortadoğu'daki İngiliz girişimlerini kuşkuyla karşılamıştır. Bu bağlamda Irak’ta ticari imtiyazlara sahip olan Lynch

\footnotetext{
${ }^{13}$ Fabrikada görev yapan muhasebe elamanı, din görevlisi, tercüman ve diğer çalışanlara yapılan ödemelerde sorunlarla karşılaşılmaktaydı ( Bamforth, 1948.19).
} 
kumpanyası1866'da imtiyazlarını Bağdat'a getirmek istediği pirinç- pamuk temizleme(çırçır), birkaç buharlı makine, buharlı pompa(sulama için) için genişletme girişiminde bulunmuştu ( Bamforth, 1948 :115).Ancak şirket Namık Paşa'nın engelleyici tavrıyla karşılaşmıştır. Bu olay sonucunda Namık Paşa İngiltere hükümeti tarafından şiddetli bir protestoya maruz kalmıştır (Bamforth, $1948: 116$ ).

İngilizlerin alternatif üretim alanları arayışının sonunda Ege kıyıları öne çıkmıştır. Bu bağlamda İngiliz firmaları 1860'lardan itibaren İzmir çevresinde kapitalist çiftlikler kurdular. Ancak emek piyasasındaki sorunlardan dolayı işletmelerde başarı sağlanamamıştır ( Tekeli, İlkin,2009:127).Avrupa'da sanayi devriminin kök salmasından sonraki süreçte Osmanlı tekstil sektörünün gelişimi Batıdaki gelişmelere bağlı kalmıştır. Osmanlı tekstil sektörü Tanzimat fermanın ilanıyla esnafın tekelci imtiyazlarını kaybetmesiyle gerilerken, ancak küresel gelişmelere bağlı olarak kısa süreli genişlemeler gerçekleştirebilmiştir. Bu bağlamda Amerikan iç savaşının gerçekleştiği 1860'larda dünyada pamuk fiyatlarında artışlar meydana gelmiş ve bunun sonucunda İngiliz dokuma sanayisi alternatif piyasalara yönelerek Osmanlı pamuk üretimi üzerinde olumlu gelişmelere sebep olmuştur ( Tekeli, İlkin, 2009:129)

\section{Yüzyıl'da İstanbul'da Boyacılık Sektörünün Gelişimi}

İstanbul'da 18 yüzyıl başlangıcında boyacıllı sektöründe en somut gelişme Sultan III. Ahmed'in Enderun avlusunda inşa ettirdiği kütüphanenin vakıf akarına bağlı olarak kurmuş olduğu boyahane ile gerçekleşmiştir (Kala,1997:170). Vakfin yönetimi selatin müessesi olmasından dolayı Darüssaade Ağalığına bağlanmıştır. Vakfın kuruluş dönemi kültürel ve ekonomik bir gelişim sürecine olan Lale devrine karş1lık gelmektedir. Vakfin tesis tarihi tam olarak kütüphane kapısı üzerindeki kitabeye göre 1709 senesidir (Başbakanlık, 2000: 464).

Boyahanenin kurulduğu yer Binbirdirek sarnıcının üzerindeki 1660'da yangınında tahrip olan Fazlı Paşa sarayıdır (Kala,1997: 170).Fazlı Paşa sarayındaki boyahanenin faaliyete geçmesi aşamasında İstanbul'da (Sur İçinde) genelinde 30 kadar üretim tekeli imtiyazına sahip olmayan(gediksiz) boyacı ustası bulunmaktaydı. Bu dönemde Galata, Tophane, Hasköy ve Eyüp'te faaliyet göstermekte olan gedikli ustaların sayısı ise 42 kişiden ibaretti. ${ }^{14}$ (Kala, 1997:170).

\footnotetext{
${ }^{14}$ Fazıl Paşa Sarayı dışındaki ustaların mahallere göre dağılımı ise şöyledir; Galata; 13, Üsküdar; 13, Eyüp, 1, Hasköy, 1, sair Perakende olan esnafla birlikte toplam 42 Gedik dükkân. (Kala,1997:170).
} 
Darüssade ağalığı piyasa da boyacılık lehine tahakkuk eden talep ve ilgili işkolundaki esnaf onaylarının alınması üzerine Fazlı Paşa Sarayı yerinde oluşturan vakıf akarlarındaki gedik konusunu(faaliyet alanını) boyacılık gediği olarak belirlemiştir (Kala,Cilt I:252). Burada faaliyet gösterecek olan gedikli esnaf vakfa günde 60'ar akçe kira bedeli ödemekle de mükellef olacaklardır (Kala,Cilt I:287-289). Kira bedeli ödeme yükümlülüğü gedikli esnaf üzerinde olup gedik sahibi olmayan diğer usta ve kalfalar ise kira ödemekten muaf tutulmuşlardı ((Kala,Cilt I:252). Boyacı esnafı mali yükümlükleri bakımından İstanbul'da Gümrük mukataasına bağlanmışlardı. Vergiler ödeme yükümlüğü kumaş üretimi kalite garantisi gerektirdiği için damgalama işlemine tabii tutulmuştu ( Faroqhi, 2000:155). Fazlı Paşa'daki boyacılık loncasına dâhil olmamakla birlikte bu iş kolunun bir yan sektörü olarak Akçıllık iş kolunda da 22 esnafa gedik hakkı verilmişti. Akçı esnafının faaliyetleri ipek ve ibrişim iplik(ipek) ve kumaşların rengini açmakla sınırlandırılmış ve boyacı nizamnamesiyle kendi faaliyet alanlarının dışına çıkmaları sınırlandırılmıştı. Fazlı Paşa sarayı boyacı esnafı gedikleri olmayan Gedik Paşa'da Hoca Hanında faaliyet gösteren iki akçı esnafının da kendi gediklerine akçı gediği ismiyle dâhil olmalarını talep etmişlerdi. Böylelikle boyacılık mesleği yeterliliğe sahip olan iki akçı esnafının faaliyetlerini de birlikte bulunacakları aynı fiziki alan sayesinde kontrol altına alınabilecekti.

Boyacı ve akçı iş kolunda faaliyette bulunanlar sadece gedikli esnaftan ibaret olmayıp bunların dışında "hamdest" olarak tanımlanan gediksiz esnaflarda faaliyetlerini sürdürmekteydi. Hamdest olarak tanımlanan şahıslar boyacılık yanında kumaş ticaretiyle de iştigal etmekteydiler. Bu esnaf ticari faaliyetlerin yoğunluğundan dolayı Gedikpaşa Bedesteni ile Simkeşhane deki vakıf dükkanlarında kendilerine yer bulabilmişlerdi. Dokuzu Yahudi ve biri de Ermeni olan bu tüccarlar hiçbir boyacı veya akçı nizamına tabii olmadan boyacılık iş kolunda kaçak olarak faaliyetlerini sürdürmekteydiler (Kala,Cilt I:213 ). Enderun vakfı akarı boyahanesinin faaliyete geçmesinden sonra İstanbul sur içinde kaçak olarak faaliyet gösteren hamdest boyacı ve akçıların nizam altına alınması da mümkün olmuştur. Çünkü vakıf kuruluş senedinin ayrılmaz bir unsuru olan boyacı esnaf nizamı sayesinde gedikli esnaf belirli bir coğrafi bölgede ilgili iş kolundaki faaliyetleri de denetlemek ve durumu karara bağlamak yetkisine de sahipti. Her ne kadar nizamname sayesinde gedikli esnaf gediksiz çalışanları şehirden ihraç etme yetkisine sahip olsalarda, 1761'de kaçak olarak çalışan sur içi esnafın gelecekteki durumunu belirlemek için oylamaya gitmişlerdi. Gedik Paşa'da akçılık yaptıkları 
belirlenen biri Hıristiyan, sekizi Yahudi toplam 9 esnafın oylama sonucunda Fazıl Paşa Sarayında gedikli olarak faaliyet göstermeleri durumu oylanmıştır. Oylama esnasında Hıristiyan ustalar nizamname hükümlerindeki amil olmasından hareket ederek gediksiz esnafın İstanbul'dan ihraçları yönünde oy kullanmışlardır. Müslümanların ise oylamaya konu olan esnafin kadimden beri bu iş yapmaları ve mesleğin gerektirdiği liyakate sahip olmaları gerekçeleri ile olumlu oy kullanmışladır. Olumlu oy kullananların öne sürdükleri argümanlardan biri diğeri de gediksiz olarak gerçekleştirilen faaliyetlerin iş hacimlerini olumsuz olarak etkilememiş olmasıdır.

İstanbul'da Yahudilerin Fazlı Paşa sarayındaki Boyacı esnafına 1761'de dahil olmaları, Yahudilerin dini temelde genel olarak ekonomik yaşamdan dişlandıkları anlamına gelmemektedir. Mesela İstanbul'da Kürk boyacılığı faaliyet alanının darlığına bağlı olarak Laleli Çeşmesi Vakfına gelir olmak üzere Hasköy'de iki dükkân gediği Yahudi esnafa münhasırdı. Hasköy’de faaliyet gösteren Yahudi esnafı kürk ile kalpakların etrafındaki kürk aksesuarları boyama tekeline sahiplerdi. Yapılan işin sınırlı olmasına bağlı olarak iki dükkan gediğinde indirgenmiş faaliyetler, tekel hakkındaki sınırlamaya bağlı olarak Laleli Çeşmesi vakfına her ay 20 'şer guruş gibi oldukça yüksek kira bedelleri de ödemekteydiler (Kala, Cilt II 117).

Yahudilerin 18.yüzyılda İstanbul tekstil sektöründe tulumbacı şeritlerinin dokunmasındaki ağırlıkları öne çıkmaktaydı. Tulumbacı şeritleri İstanbul ve Hasköy’de ipek üzerine gerçekleştirilen işlemelerle gerçekleştirilmekteydi. Bu esnaf kolundaki esnafın 1774'de etnik temelde dağılımları ise;

İstanbul'da 18.Yüzyılda Tulumbacı Şeridi İmalında Yahudilerin Yeri

\begin{tabular}{|l|l|l|}
\hline Esnafin Dini Kökeni & Esnaf Sayıs1 & Tezgah Sayıs1 \\
\hline İslam & 14 & 20 \\
\hline Zimmî & 10 & 20 \\
\hline Yahudi & 85 & 110 \\
\hline Toplam & 112 & 150 \\
\hline
\end{tabular}

Kaynak; İstanbul Ahkâm Defterleri, Esnaf Tarihi, Cilt II, s.165. göre hazırlanmıştır.

Şerit dokumacılığında ipek üzerine işlemelerinin yapılması mal fiyatını arttıran önemli bir unsurdu. Yahudi ustalar 1774'de Divanı Hümayuna gerçekleştirmiş oldukları başvurularıyla 
şerit fiyatlarının düşürülmesi için ipeğe alternatif olarak Venedik Tiresi kullanılmasını teklif etmişlerdir. Yahudi esnafin talepleri yerinde bulunarak Venedik Tiresi kullanımına izin vermişse de, genel ekonomik dengeyi göz önünde bulundurarak verilen izni 51 esnaf ile sınırlandırmıştır (Kala, Cilt II,1997:165).

Osmanlı Yahudileri Avrupa'daki emsallerine göre daha olumlu ekonomik yaşamda daha olumlu hukuki koşullara sahiplerdi. Mesela 18.yüzyılda bir şirkete üye olabilmek için girişimcilerin yaşadıkları şehirlerde gedik belgesine emsal "serbestlik belgesine" sahip olmaları gerekmekteydi. Yahudilere şehir yönetimleri tarafından serbestlik belgesi verilmediği için Yahudi ve Hristiyan olmayanların kumpanya veya lonca üyesi olabilmeleri mümkün değildi ( Wood,2003: 205).Fazlı Paşa sarayındaki gedik kapsamının genişletilmesi her kadar Müslüman esnafların vermiş oldukları oylarla mümkün olmuşsa da yeni katılanlara bir tazminat bedeli de yüklenmişti. Belirlenen tazminat bedeli vakfa kira olarak ödenecek olup, bu bedel kendilerinin vakfa ödedikleri yevmiyenin iki katı olan 120 akçe olarak süresiz olarak belirlenmiştir. Böylelikle Fazıl Paşa Boyahanesine sonradan katılanlar vakfa senede 360 guruş ödemeyeceklerdir. Loncaya yeni katılanlar faaliyetlerini eski yerlerinde sürdüremeyecek olup Fazıl Paşa Sarayında kendileri için inşa edilecek olan yeni boyahanelerde sürdüreceklerdir (Kala,Cilt II,1997:287-89). Boyacı esnafının sahip olduğu imtiyazlı üretim ilişkisinin istikrarlı bir şekilde sürdürülmesinde nizamnamenin varlığı ve içeriği önem arz etmekteydi. Ancak devletin iktisadi hayata bakışı açısı bakımından da piyasada kıtlık sorunuyla karşıllaşmamak da diğer bağlayıcı bir faktördü. Piyasanın düzenlenmesindeki bu düalist bakış açısı zaman zaman devletin öncelikleriyle esnaf örgütlenmesinin önceliklerini karşı karşıya getirebilmekteydi. Bu gibi durumlarda sorunun giderilmesinde, esnaf bakımından olduğu kadar devlet içinde bağlayıcı bir metin olmasından dolayı nizamnamenin varlığ örneklemesi bakımından boyacı esnafının $1755^{\prime}$ de karşılaştığı bir olay oldukça açıklayıcı bir mahiyete sahiptir. Vakıf yönetimi 1755'de Fazlı Paşa Sarayındaki Boyacı dükkânlarının yetersizliği gerekçesiyle yıkılarak yeniden inşaları yönünde bir karar almıştı. Boyahanelerin yıkımı esnasında İstanbul'daki gediksiz faaliyette bulunan esnaf Divanı Hümayun Kalemine müracaat ederek, boyacılık faaliyetlerini legal bir zeminde sürdürmek için ferman talebinde bulunmuşlardır. Gediksiz esnafın ferman talebi divan tarafından üretim tıkanıklığı olma durumunun engellenmesi gerekçesi ile kabul edilmiştir. Ancak fermanla sağlanan hukuki haklar vakıf dükkânları inşasının tamamlanmasına kadar geçecek süreyle sınırlandırılmıştır. Yeni boyahaneni inşasına kadar geçecek sürede esnaf başına günlük üretimde 60- 70 dirhemlik 
olarak sınırlandırılmıştır. Ancak inşa sürecinde gediksiz esnafın almayı başardığı bu ferman, gedikli esnafların mahkemeye itirazı ile karşılamıştır. Eminönü Kadılığı mahkeme neticesinde fermanda verilen hükmü boyacı nizamnamesinin yürürlükte olduğu gerekçesiyle bozmuştur (Kala, Cilt II,1997.108).Bu durum merkezi idari maslahattaki tasarruf alanının mutlak olmadığının ve yargı bağımsızlığına dayalı hukuki denetime tabii olduğunun göstergesidir.

$\mathrm{Bu}$ durum karşısında merkezi idare gedik arttırma tasarrufunun hukuk sistemi tarafından sınırlandırılması üzerine piyasadaki genişleyen iş hacmini gerekçe göstererek tezgah sayısının arttırılmasına yönelmiştir (Kala,Cilt II,1997:103).

Fazlı Paşa sarayında dükkan inşasının tamamlanması 1758'de tamamlanmıştır. Böylelikle yayımlanan ferman doğrultusunda vakıf yönetimi ve boyacı loncasının uzlaşması gerçekleştirilerek daha önce otuz adet tezgâh sayısı 70'e çıkarılmıştır. Tezgah sayısındaki artış kalfaların ustalık statüsüne yükseltilmesi ile sonuçlanmıştır. Tarafların uzlaşması sürecinde vakıf idaresinin akar gelirlerini arttırma amacı ile esnafın ipek başta olmak üzere hammadde tedarikinde istikrar beklentisi öne çıkmıştır (Kala,Cilt II,1997:170). İstanbul'da tekstil sektöründeki gelişmeye bağlı olarak boyacı esnafı gedik ve ustalık beratlarındaki artış zamanla Müslüman esnafın sayısal üstünlüklerini Hristiyan ve Yahudiler karşısında kaybetmeleri sonucunu doğurmuştur. Fazlı Paşa sarayı vakfının kurulduğu 1709'da 20 Müslüman esnafa karşın 10 gayrimüslim esnafin gedik hakkı bulunmaktaydı (Kala,Cilt,I, :287-89).1761'e kadar olan süreçte 9'u Yahudi biri Hristiyan olmak üzere toplam 10 kişinin oylama sonucu sisteme dahil olmasıyla gedik sayısı taraflar arasında 20'şer olarak eşitlemiştir. Yeni boyahanein tamamlanmasıyla 70 kalfanın gayrimüslümün ustalık beratına sahip olmalarıyla toplam esnaf sayısı 110'a çıkmış olmasına karşın Müslümanların sayısı 1709'da olduğu gibi 20 ile sınırlı kalmıştır. İstanbul'da 1760'da boyacı sayısındaki artış sur dışında da genişleme göstermiştir. Bu dönemde iş hacmindeki artışa bağlı olduğu gerekçesiyle Üsküdar Ayazma camisi inşasının tamamlanması üzerine vakıf akarı olarak, Ayazmada 30 birim boyahane gedikli dükkanı inşa edilmiştir (Kala,Cilt I,:282-283). Sultan III. Ahmet tarafindan kurulan Enderun Kütüphanesi vakfına gelir olarak Gazzaz esnafının İbrişsim bükme faaliyetleri de gediğe bağlanmıştı. İbrişim bükücü esnafına gedik olarak bağlanmış olan 30 dükkân ve 70 usta ile gediğe bağlanmıştır. İbrişim bükücü esnafın vakfa ödemesi gereken icar bedeli de senede 2000 guruş olarak belirlenmiştir (Kala,Cilt II,1997: 171).Gazzaz esnafi İstanbul'da İbrişim bükme tekeline sahip olmalarına karşın, şehir dışında bükülmüş İbrişimlerin satışını engellemeye yönelik imtiyazlara sahip değillerdi. Bu esnaf kolunda tekel hakkının imalatla sınırlı olması İstanbul'a ticaret 
yoluyla gelen mal piyasasında toplam talebi karşılama yeterliliğinden kaynaklanmaktaydı (Kala,Cilt II,1997: 75).

İstanbul ve sur dışındaki boyacılık faaliyetlerinin gelişimi yakın yerleşim yerlerinde de gerçekleşmiştir. Mesela 1762 'de İzmit'te boyacı esnafı üretim tekelini sağlamaya yönelik olarak bir araya gelerek İzmit Boyacı Karhanesi İstanbul'daki emsallerinde farklı olarak bir vakfiye senedinden bağımsız olarak serbest boyacı esnafı tarafından kurulmuştur. Esnafin ortaya koymuş olduğu girişim hücceti şeriye ile kamu idaresi tarafindan da onaylamıştır. Ancak İzmit esnafına sağlanmış olan bu imtiyaz alanının somutlaşmasına yönelik bir adım da atılarak ilgili karhane İstanbul Gümrüğü Mukataasına dâhil edilmiştir. İzmit boyahanesinin İstanbul Gümrük mukataasına bağlanması, İstanbul boyahanesinin de dâhil olduğu gümrük mukataasını genişletici bir tasarruf olmuştur ( Özvar,2003:80). Tamamı zimmilerden oluşan İzmit boyacı karhanesi esnafı tekel haklarının korunması talebiyle divana arz etmiş oldukları arzuhallerinde gerek imalat kalitesinde istikrarın korunması gereği ve gerekse de ödemekte oldukları vergilerde sürekliliğin korunması argümanlarına dayanmışlardır (C.İKTS. 4-177, 28.08.1176). İzmit esnafının edinmiş olduğu tekel hakları İzmit kırsalını da kapsamaktaydı. Ancak kırsalı da kapsayan tekel hakları zamanla iş hacminin genişlemesine bağlı olarak yeni gediklerin tesisine de yol açabilmekteydi. Mesela Silivri'de 1743 senesinde iki zimmî ustaya gedik hakkı iş çokluğu ve halkın ihtiyacı gerekçeleriyle verilmişti. ${ }^{15}$ (Kala,Cilt II,1997:14).

\section{Yüzyıl'da diğer Boyacılık Faaliyetleri}

Boyacı esnafı iş kolunda faaliyette bulunmakla birlikte al, elvân, lâl ve kürk Boyacıları farklı kategorilerde faaliyetlerini sürdürebilmekteydiler (Kala,Cilt II,1997: 10).Bunlardan ön önemlisi ise yapılan işin gelişmiş uzmanlık gerektirmesinden dolayı al boyacılıktı. Al boyacı esnafı sandalcı esnafindan gelen kumaşları al, penbe ve gülgûnî renklere boyamaktaydılar. Belirtilen renklerden başka diğer renklerde boyama faaliyetleri ise İstanbul, Galata, Üsküdar ve Eyüp'te faaliyette bulunan Elvan Boyacılar tarafından gerçekleştirilmekteydi. Al boyacılıkta

\footnotetext{
${ }^{15}$ Zımmi ustaların faaliyetlerine müdahale edenler olup, bunlar yine zımmi statüsündedir. (Kala,Cilt II,1997:14).
} 
kullanılan başlıca hammaddeler usfuri mısri ve zerdeçav olup ilgili maddeleri alım tekelleri bu esnaf kolunun tekelindeydi. Osmanlı boyahanelerinde kullanılan al boya malzemeleri genel olarak ülke dahilinde doğal koşullardan elde edilmekteydi. Bunlardan uluslararası başlıca talep gören boyama maddesi ise yüksek parlaklığından dolayı talep gören kızılköktü. Kızılkök üretiminde Konya'nın Güneyindeki Ereğli önemli bir üretim merkezi konumundaydı ( Ouataert, 2013:54).

Al boyacı esnafi Mahmud Paşa bölgesinde Daye Hatun mahallesindeki İbrahim Paşa akarından olan yedi adet gedikli dükkândan oluşan kârhanede ve isimleri vakıf defterine kaydedilmiş 27 beratlı usta tarafından gerçekleştirilmekteydi. Al Boyacı esnafı piyasaya yönelik işlerinden başka ordu ve donanmanın da taleplerini de karşılamakla mükelleflerdi. $\mathrm{Bu}$ bağlamda tersane sancaklarının boyanmasından da sorumluydular ${ }^{16}$. (AE. SMHD...I, 231223).

Fazlı Paşa sarayında faaliyetlerini sürdüren boyacı esnafı al boyacı esnafının gediğinde bulunan faaliyetlerini de yerine getirerek nizama aykırı faaliyetlerde bulunabilmekteydiler. Bursa, Edirne ve İzmir'den İstanbul'a gelmekte olan boya girdileri gümrük sahası dışında boyacı esnafı tarafindan alınarak al boyacıların girdi sorunlarına sebep olarak faaliyetlerini 1766 'da olumsuz olarak etkileyebilmişlerdi ( C.İKS, 26- 1269, H.12-07-1180).Sultan Mustafa tarafından Lalelide inşa edilen camiinin (Laleli Camii) vakıf akarına bağlanmak üzere Langa Yeni Kapısında dört kârhaneye al boyacı imtiyazı verilmiştir. Al Boyacıların tamamı 34 gedikli zimmi ustadan oluşmuştur. Vakfin bu kârhanelerden kazancı 7500 guruş muaccele ve 6000 guruş müeccele ile mukataa olarak mali sisteme dâhil edilmiştir. Ancak Langa Yeni Kapıda inşa edilmiş olan kârhanenin sur dışında olması kadın müşteriler tarafından rağbet edilmemesi sonucu doğurmuştur Kala,Cilt II,1997:295). Her ne kadar al boyacı esnafı sur içinden yer talep etmişseler de bunlara yeni bir yer verilmediğinden dolayı faaliyetlerini Langa Yeni Kapısında sürdürmeye devam etmişlerdir (C.İKTS.36/ 1752, h.25-10- 1206).

Elvan boyacılar kumaşları al renge boyamak için piyasadan nizamnameye aykırı olarak temin ettikleri usfuri mısri ve zerdeçav girdi mallarına ulaşarak al boyacıların nizamlarına muhalefet etmekteydiler. İlgili hammaddelerin piyasasındaki kontrolün sağlanmasındaki güçlük İbrahim Paşa vakfı tarafından 27 ile sınırlandırılmış olan usta sayısının 50'e ulaşmasından

\footnotetext{
${ }^{16}$ Donanmayı Hümayun 1734'de al boyacı esnafı kethüdasından Yuvan'ın sancakların kırmızıya boyanması için görevlendirilmesini talep etmiştir Yuvan’a yapacağı iş karşıllı̆ında 6000 akçe ödenecektir. (AE. SMHD...I, 231223).
} 
kaynaklanmaktaydı. Divanı Hümayun tarafından bu girdilerin piyasasında mal arzını kontrol altına almak gayesiyle 1776 'da gerçekleştirilen hususi bir tahrir çalışmasıyla esnaf sayısı vakfiyeye uygun olarak 50'den 27'e düşürülmüştür (Kala,Cilt II,1997:258). Ancak elvan ustaların al boya imalatıyla uğraşmaları yasağını sağlamak amacıyla 1759 ile 1776 yılları arasında emirler yayınlaşmışsa da sonuç alınamamıştır Kala,Cilt II,1997:294). İstanbul sur içindeki boyacılık faaliyetlerinin dışında en yaygın faaliyetler Galata da 17 gedik dükkanında gerçekleşmekteydi. Galata'daki boyacı esnafının tamamı gayrimüslümlerden oluşmaktaydı. Ancak yönetici konumunda olan kethüdaları aynı zamanda bir kamu görevlisi olma sıfatına haiz olan Hasan Usta isimli bir Müslüman'dır. Esnafın doğrudan temsilcisi olan yiğitbaşıları ise Dimitri isminin taşımaktaydı. Galata boyahanesinin faaliyetleri, Fazıl Paşa Sarayından boyacılık faaliyetlerini kapsamaktaydı. Yani boyacıların coğrafi temelde farklılaşmış faaliyetleri iş uzmanlığında da farklılaşmıştı. Galata boyacılığını İstanbul'daki emsallerinden farklılaştıran uzmanlık alanları Mihaliç, Gedüs, Yelken, Melez, Keten ve Sakız bezlerinin boyanmasıyd1 Kala,Cilt II,1997:264).

\section{İstanbul Taşrasında Boyacılık}

İstanbul taşrasında boyacılık faaliyetlerinin gerçekleştirildiği yerlerden biri de Silivri'dir. Silivri'de boyac1lık nahiye merkezindeki 30 gedikten müteşekkil boyahanede faaliyette bulunmaktaydı Kala,Cilt II,1997:89). Silivri'de boyacı esnafı gayrimüslimlerden oluşmaktaydı. Ancak boyahaneden başka Silivri nahiyesi ile Sarı, Fener ve Çandi köylerinde de gedik hakkı olmayan boyacılık faaliyetleri de kaçak yollarla yine gayri Müslümler tarafindan gerçekleştirilmekteydi (Kala,Cilt II,1997:81). Silivri boyahanesi taşrasındaki boyacılık faaliyetleri kırsaldaki insanlarla boyahane esnafının karşı karşıya gelmesine de sebep olabilmekteydi. Mesela 1765'de Sarı köyünde faaliyette bulunan Anaştaş'ın ancak Silivri boyahanesinde faaliyette bulunabileceği ihtarı karşısında köy sakinleri gerek ustanın mahareti gerekse de köylerinin Silivri’ye uzaklığ 1 gerekçesiyle bu faaliyete müdahale edilmemesini Silivri kadısından talep etmişlerdi. Kırsaldaki boyacılık faaliyetleri hem boyahanenin kırsaldaki yerleşim alanlarından uzaklığı hem de lonca tarafından ihtara maruz kalmış olan esnafın ustalığına halkın yapmış olduğu şehadet ile kadılık onayı ile yapılabilmekteydi Kala,Cilt II, 1997:97).

İstanbul Galata'da 8'i yeni 7'si ise eski kumaş(elvan) ve bezler olmak üzere tamamı gayrimüslimlerden oluşan 15 esnaf faaliyet göstermektedir. Boyanan kumaş türleri yelken 
bezinden keten kumaşlara kadar geniş bir çeşitliliğe sahipti. Galata'da faaliyette bulunan esnaf toplu olarak bir yerde toplanmamıştır. Bu durum esnafın ve kalp iş yapanların denetlenmesini zorlaştırdığı için 1775 'de Galata Boyacı esnafının Camii Cedid civarında toplanmasına Divanı Hümayunda karar verilmiştir (Kala,Cilt II,1997:175).

\section{8.yüzyılda İstanbul'da Genel Olarak Tekstil Ticareti}

İstanbul tekstil piyasası bu şehirde imal edilmeyen ürünlerin ticaretlerine sağlanmış olan ticari tekeller üzerinden gerçekleştirilmekteydi. Ticarete konu olan tekstil ürünlerine sağlanmış olan imtiyazlar kamu tarafından gümrük işlemlerine yani dahili vergilendirmeye tabii tutulmasıyla hazine iradına yansımaktaydı. Tekele bağlanmış olan ticaret, esnaf örgütünün mal arzının karşılanmasındaki rolüne işlevsellik kazandırmaktaydı. Mesela bir keçe türü olan İmroz(Gökçeda) kemesi kemeci esnafi tarafindan Zindan Kapıda gümrügü ödendikten sonra şehre girebilmekteydi. İmroz kemesi ticareti Rüstem Hanı civarındaki Çukur hanında gerçekleştirilmekteydi (Kala,Cilt II,1997:99). İstanbul'da doğrudan ticarete konu olan tekstil ürünlerinden sof kumaşı öne çıkmaktaydı. Sof kumaşı ticareti 1708'den beri Amcazade Hüseyin Paşa vakfına ait Tavuk Pazarın'da Bezzazistan civarındaki Sofcu Hanında gerçekleştirilmekteydi. Sof kumaşı tekelinin Sofçu hanındaki esnaf tekelinde olması 1765'e kadar olan süreçte 3 hücccet, 3 ilam ve 1 hattı hümayun ile teyit edilmişti. Hattı Hümayun Sultan I. Mahmut tarafindan 1742'de yayımlanmıştır. Sof kumaşı İstanbul'a Ankara'dan gelmekte olup, Ankara tamga mukataasına tabi olarak vergilendirildikten Sofcu hanında ticaret konu olmaktaydı. Sofcu hanı dışında ticarete konu olan mallar Tahtahan'da bazı Ankaralılar tarafından nizamnameye aykırı olarak ticarete konu olabilmekteydi. Tahtahan'da gerçekleşen sof ticareti hem vergi geliri kaybına hem de nizamnamede belirlenen standartlara uymadığ 1 gerekçeleriyle Sofcu esnafının şikayetine konu olabilmekteydi (İstanbul Ahkâm Defterleri, Esnaf Tarihi, Cilt II, s.108). Sof kumaşı ticaretine verilmiş olan tekel hakkının ihlali parçası esnafi tarafindan gerçekleştirilmektedir Kala,Cilt II,1997:101).

Osmanlı yelken bezleri yüksek fiyat düzeylerine rağmen yüksek kalitelerinden dolayı uluslararası ticarette rağbet gören bir üründü ( Tabakoğlu, 1994:224).İstanbul'da yelken bezi Eski Tersanede Nessecan Esnafı tarafından Dimici ipliği denilen bir pamuklu iplik kullanılarak imal edilmektedir. Nessecan esnafi İstanbul'a zahire getiren gemilere topu 22 guruş narh fiyatından satmakla mükellef olmalarına rağmen 1767 'de zahire gemilerinin kaptanları narh 
fiyatına riayet edilmediği için İstanbul kadısına şikâyet etmişlerdir. Gemi kaptanlarının iddiasına göre İstanbul'a gelen Fransız gemileri yelken bezinin topuna 35 guruş ödedikleri için, Nessecan esnafı da kendilerine 37 guruştan daha aşağı satmaya yanaşmamışlardır Kala,Cilt II,1997:134). Yelken bezi örneğinde olduğu gibi uluslararası talebi olan bir malın üretimi piyasa koşullarından ziyade kamusal bir müdahale ile sınırlandırılmaktaydı. Çünkü Osmanlı devlet anlayışında iktisadi çıkarcılıktan ziyade siyasal denge anlayışı öne çıkmıştır ( Pamuk, $2017: 62)$.

\section{SONUÇ}

İstanbul'da 18.yüzyıl'da selatin vakıfları statüsünde Fazlı Paşa Sarayı, Hasköy ve Langa Kapısında inşa edilen boyahaneler tekstil sektöründeki gelişiminden yararlanmak amacını yansıtmaktadır. Bu vakıfların mali sisteme eklemlenmenin göstergesi olan mukataa oluşumları da kamu bakımından gelir istikrarını sağlanması amacını taşımıştır. Boyahane tesislerinin gerek mali gerekse de üretim istikrarını sağlamak amaçlarıyla üstlenmiş oldukları tekelci üretim ilişkileri iktisadi gelişim üzerinde sınırlandırıcı etkiler meydana getirmemişlerdir. Ancak Osmanlı ekonomisinde genel denge yaklaşımını temsil eden provizyonist ilkelere dayalı üretim ilişkisi, Batı Avrupa'da ekonomik birikim artışı ve büyüme stratejisini temsil eden merkantilist politikaların performansına karşılık verememiştir.

\section{KAYNAKLAR}

\section{Basılı Kaynaklar}

Ahmet Tabakoğlu, Türk İktisat Tarihi, Dergah Yayınları, İstanbul, İkinci Baskı, 1994.

Donald Ouataert, Sanayi Devrim Çağında Osmanlı İmalat Sektörü, Çev; Tansel Güney, İletişim, 4. Baskı İstanbul, 2013.

Suraiya Faroqhi, Osmanlı'da Kentler ve Kentliler, Çev; Neyyir Kalaycıoğlu, Tarih Vakfı Yurt Yayınları, 3. Baskı, Tarih Vakfı Yurt Yayınları, İstanbul, 2000, s.155.

Şevket Pamuk, Osmanl1-Türkiye İktisadî Tarihi, İletişim, İstanbul, 2017.

Phyllis Deane, İlk Sanayi İnkılabı, Çev; Tevfik Güran, TTK, Ankara, 1994.

Mehmet Genç, Devlet ve Ekonomi, Ötüken, 10. Baskı, 2000. 
Tahir Öğüt, 18-19. Yüzyılda Urfa Şehrinin İktisadi ve Sosyal Yapılanmasında Rızvaniye Vakfının Yeri, İstanbul Üniversitesi Sosyal Bilimler Enstitüsü, Basılmamış Yüksek Lisans Tezi, 1999.

Mehmet Genç, Devlet ve Ekonomi, Ötüken, 10. Bask1, 2000, s. 132.

İstanbul Ahkâm Defterleri, Esnaf Tarihi, Cilt I., Yayına Hazırlayan, Ahmet Kal'a, İstanbul Büyük Şehir Belediyesi Kültür AŞ Yayınları, 1997.

İstanbul Ahkâm Defterleri, Esnaf Tarihi, Cilt II., Yayına Hazırlayan, Ahmet Kal'a, İstanbul Büyük Şehir Belediyesi Kültür AŞ Yayınları, 1997.

Başbakanlık Osmanlı Arşivi Yayınları, Yayın No; 42, s. 464, İstanbul, 2000.

Alfred Wood, Levant Kumpanyası Tarihi, çev; Çiğdem Erkal İpek, Doğubatı, Ankara, s. 205.

Erol Özvar, Osmanlı Maliyesinde Mâlikane Uygulaması, Kitabevi, 2003, İstanbul.

Doğan Avcıŏlu, Türkiye’nin Düzeni, Kırmızı Kedi Yayınları, İstanbul, 2013.

Paul Kennedy, Büyük Güçlerin Yükseliş ve Çöküşleri, Çeviren; Birtane Karanakçı, İş Bankası Kültür Yayınları, 14. Baskı, İstanbul, 2008.

Hüseyin Çınar, Hüsrev Paşa Vakfı'nın Ayıntab'daki Vakıf Boyahaneleri, Vakıflar Dergisi, Sayı 40, Aralik 2013.

İlhan Tekeli- Selim İlkin, “Osmanlı İmparatorluğu'nda 19.yy’ın İkinci Yarısında Nafia Programları ve Teknoloji Gelişim Üzerine”, Cumhuriyet'in Harcı, Cilt 3, ss.123-175, İstanbul.

Tahir Öğ̈ut, (2018) “18TH Century Provincial Administration of Ottoman Empire in War Economy; Raqqa Province(1730- 1745”, Economic Issues in Retrospect And Porspect, Aleksandra Gorecka- Altuğ M.Köktaş, Agnieszka Parlinska, Vol.II, IJOPEC, London: 265-290.

Tahir Ögü̈t, İktisadi Yönüyle Osmanlı Vakıflarında Su Kaynaklarının Yönetimi- 18.ve 19.Yüzyıllarda Urfa Vakıfları Örneği, Yönetim ve Ekonomi Araştırmaları Dergisi, Cilt 7, Sayı 1, 2019, ss357-376.

Winifred Bamforth, British Interests In The Tigris- Euphrates Valley; 1856- 1888, M.A., 1948. Edward Mead Earle- Bağdat Demir ve Petrol Yolu Savaş1(1903-1923), Örgün Yayınevi, İstanbul.

\section{Arşiv Kaynakları}

AE. SAMD. II, 20/ 2186. 

(FSECON ÖĞÜT, T.(2019), "Sanayi Devrimi Başlangıcında İstanbul'da Boyacı Esnafi Örneğinde Tekstil Sanayisinin Durumu”,
Fiscaoeconomia, Vol.3(3), 181-197.

C.İKTS, 26- 02-1133, h.29.2.1133.

C.İKT, 38/ 1863, H.23-12-1178.

AE. SMHD...I, 23-1223

C.İKS, 26- 1269, H.12-07-1180

C.İKTS.36/ 1752, h.25-10- 1206

C.İKTS. 4-177, 28.08.1176.

A.DVN.MHM. 10/237,h. 17.10.979. 